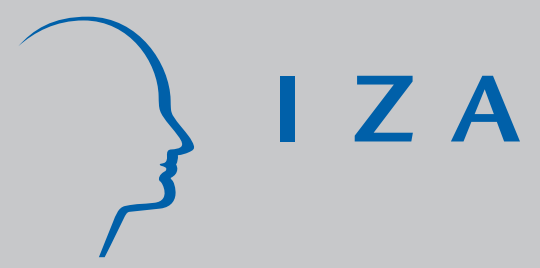

IZA DP No. 614

Long-Term Effects of Unpaid Overtime:

Evidence for West Germany

Markus Pannenberg

October 2002 


\title{
Long-Term Effects of Unpaid Overtime: Evidence for West Germany
}

\author{
Markus Pannenberg \\ DIW Berlin and IZA Bonn
}

\author{
Discussion Paper No. 614 \\ October 2002
}

\author{
IZA \\ P.O. Box 7240 \\ D-53072 Bonn \\ Germany \\ Tel.: +49-228-3894-0 \\ Fax: +49-228-3894-210 \\ Email: iza@iza.org
}

This Discussion Paper is issued within the framework of IZA's research area Mobility and Flexibility of Labor. Any opinions expressed here are those of the author(s) and not those of the institute. Research disseminated by IZA may include views on policy, but the institute itself takes no institutional policy positions.

The Institute for the Study of Labor (IZA) in Bonn is a local and virtual international research center and a place of communication between science, politics and business. IZA is an independent, nonprofit limited liability company (Gesellschaft mit beschränkter Haftung) supported by the Deutsche Post AG. The center is associated with the University of Bonn and offers a stimulating research environment through its research networks, research support, and visitors and doctoral programs. IZA engages in (i) original and internationally competitive research in all fields of labor economics, (ii) development of policy concepts, and (iii) dissemination of research results and concepts to the interested public. The current research program deals with (1) mobility and flexibility of labor, (2) internationalization of labor markets, (3) welfare state and labor market, (4) labor markets in transition countries, (5) the future of labor, (6) evaluation of labor market policies and projects and (7) general labor economics.

IZA Discussion Papers often represent preliminary work and are circulated to encourage discussion. Citation of such a paper should account for its provisional character. A revised version may be available on the IZA website (www.iza.org) or directly from the author. 
IZA Discussion Paper No. 614

October 2002

\section{ABSTRACT}

\section{Long-Term Effects of Unpaid Overtime: Evidence for West Germany*}

Why do people work unpaid overtime? We show that remarkable long-term labor earnings gains are associated with unpaid overtime in West Germany. A descriptive analysis suggests that over a 10-year period workers with unpaid overtime experience on average at least a 10 percentage points higher increase in real labor earnings than their co-workers. Applying panel data models this result generally holds. Furthermore, we find some evidence for gender specific differences with respect to the effects of unpaid overtime work. Our results point to the importance of investment in current working hours beyond the standard work week to enhance real earnings prospects.

JEL Classification: J22, J23, J31, J33

Keywords: overtime, overtime compensation, labour earnings, linear panel data models

Corresponding author:

Markus Pannenberg

DIW Berlin

14191 Berlin

Germany

Tel.: +49 3089789678

Fax: +493089789109

Email: mpannenberg@diw.de

\footnotetext{
* Special thanks for helpful comments and discussions go to John Haisken-DeNew, Jenny Hunt,
} Martin Spiess, Gert Wagner and participants at ESEM2002, EALE2002, VfS2002 and GSOEP2002. 


\section{Introduction}

Unpaid work is a notable phenomenon in most industrialised labour markets, in particular for white collar workers. Recent studies for Germany and the UK (Bauer/Zimmermann (1999), Bell/Hart 1999, Bell/Hart/Hübler/Schwerdt 2000, Pannenberg/Wagner 2001) show that in West Germany roughly one out of three white collar workers and in Great Britain more than $50 \%$ of all managers, foremen and supervisors work unpaid overtime. Moreover, averaged across all workers the weekly amounts of worked unpaid overtime hours are at least as high as the paid for overtime hours in both countries. In addition it is pointed out that the estimated returns to education, experience and tenure in a standard Mincerian hourly wage equation framework are remarkably lower if one adjusts hourly wages for unpaid overtime hours (Bell/Hart 1999, Bell/Hart/Hübler/Schwerdt 2000).

In view of the observed amounts of unpaid overtime we have to ask whether the notion that this type of overtime is "unpaid" is really appropriate. Economic theory provides at least four different classes of explanations 1 that there is no such thing as "unpaid" overtime: (1) Employers and employees uncertainty about the required effort to conduct specific complex tasks leads to contracts that specify, for example, yearly income combined with a performance-related pay scheme but do not specify a binding standard working week. This might lead to persistent "unpaid" overtime beyond the non binding standard working week. (2) Overtime pay regulation at the industry level, like that observed in Germany, might lead to combinations of paid and unpaid overtime as a bargained agreement between employers and employees at the firm level circumventing these regulations. (3) Unpaid overtime might be part of a gift exchange between an employer and an employee; e.g., employees respond to employer-financed on-the-job training with unpaid overtime. (4) If firms use promotions to sort workers within hierarchies, workers exert effort in terms of current unpaid overtime among others to be promoted to better paid positions in the future. Moreover, even without

\footnotetext{
1 See Bell/Hart (1999) for a survey.
} 
explicit promotion policies workers might provide unpaid overtime, since within a forward looking labour supply model, the workers current amount of (unpaid) work hours has an impact on their advance in the distribution of earnings and this effect increases with a rise in earnings inequality (Bell/Freeman 2001).

There is some empirical evidence consistent with the sketched hypotheses. As quoted above, a lot of studies provide evidence that the likelihood of unpaid overtime increases in qualification. Since on average the complexity of a job increases with the required qualification these results are in line with hypothesis (1). Evidence consistent with the compensating differential hypothesis (2) is provided by Trejo for the US (1991). Trejo shows that workers and employers adjust the hourly wage in response to a change in the overtime premium. Pannenberg (2002) provides some evidence for a positive correlation of unpaid overtime and on-the-job training for West Germany, which is in line with hypothesis (3). Moreover, Booth/Francesconi (2000), Francesconi (2001) and Booth et al (2002) provide evidence for a significant correlation of overtime hours worked and subsequent promotions in Great Britain, though Booth et al. (2002) do not find varying effects for paid and unpaid overtime. Bell/Freeman (2001) provide supportive evidence for their forward looking labour supply model using data for the US and Germany.

In this paper we add to the existing empirical literature by assessing the long-term impact of unpaid overtime on labour earnings for Germany. We use panel data for West Germany over the period 1988 to 2000 to analyse cumulative average effects of unpaid overtime on labour earnings. We start with a brief description of the data and some descriptive evidence on the incidence and amount of unpaid overtime for our specific subsample (section II). We then provide descriptive evidence of the relationship between unpaid overtime and long-term labour earnings growth (section III). In section IV we use panel data models to assess whether observed cumulative average unpaid overtime has an impact on labour earnings. Section V concludes with a discussion of our results. 


\section{Data and basic trends}

Our empirical analysis is based on the German Socio-Economic Panel (GSOEP). The GSOEP is a nationally representative longitudinal data set for Germany which was first conducted in 1984 (Wagner et al. 1993, SOEP Group 2001). We use data for the years 1988 up to 2000. Our analysis is restricted to full-time workers living in West Germany aged 18 up to 65 in the relevant years. These workers have to remain with their firm for their specific set of observations but might experience mobility within the firm like promotions or demotions. The restriction to firm stayers allows us to disentangle the long-term impact of cumulative unpaid overtime from individual and firm specific fixed effects as well as individual and firm specific time trends. Furthermore, workers in the public sector, in agricultural, fishing or private households, self-employed persons and respondents with missing information on wages, standard and actual hours worked, overtime hours and overtime compensation are dropped.

Information on overtime incidence stems from two sources. In order to have a measure for current overtime work, we use information on the amount of overtime in the last month preceding the interview. As a measure for the average amount of overtime hours worked, we calculate the difference of average actual weekly hours worked including overtime hours and bargained weekly standard hours. With respect to usual types of overtime compensation, the questionnaire allows us to differentiate between paid overtime, unpaid overtime, overtime compensated with hours or days off and a partly paid/partly compensated with extra time off category. The wage measure used is the monthly gross real labour earnings in the months preceding the interview including overtime payments. Bonuses such as a $13^{\text {th }}$ or $14^{\text {th }}$ month salary, holiday pay, profit related pay or bonuses are drawn from the subsequent wave, divided by 12 and added to the monthly wage measure.

Table 1 displays the shares of the different types of overtime compensation for workers with overtime work in the month before the interview and their average amount of overtime hours

\footnotetext{
${ }^{2}$ From 1988 on the required information on overtime work and working hours is provided for each year.
} 
for our subsample of firm stayers. With respect to the shares of overtime compensation we do observe a share of unpaid overtime of roughly $21 \%$ of all workers with overtime incidence, which decomposes to $32 \%$ for white collar and $3 \%$ for blue-collar workers. This is close to the figures found in studies which do not restrict themselves to firm stayers. ${ }^{3}$ Moreover, table 1 reveals a dramatic decrease in paid overtime over the whole period 4 and a remarkable increase in "extra days off later on" as found in other studies for West Germany. The later mirrors the fact that in Germany both unions and employers associations are pushing so called individual "working time accounts" since the beginning of the 90's: Overtime hours are transferred into these accounts, when workers are required to work overtime due to short run fluctuations in product demand and overtime hours have to be drawn from these accounts within a given period when short-run product demand allows for a transitory reduction of individual working hours respectively. Employers surely prefer "working time accounts" over paid overtime to cope with short-run fluctuations of labour demand, since the transaction costs of a flexible working time scheme, once it is set up, are lower than costs due to overtime premiums. Unions support these accounts in light of the idea of work-sharing, i.e., the notion of transforming paid overtime into transitory overtime and allocating the remaining definite amount of overtime hours to unemployed workers.

The average amount of overtime worked, conditional on overtime incidence, under different overtime compensation regimes over all years varies between 2.9 hours for "extra days off later on" up to 6.6 hours per week for workers with unpaid overtime. Note that in all years the average amount of overtime hours with no pay in the month before the interview is greater than or equal to the average amount of worked overtime hours within any other compensation system.

3 See Bauer/Zimmermann (1999) or Pannenberg/Wagner (2001).

4 See Kalwij/Gregory (2002) for a discussion of the incidence and the amount of paid overtime in Great Britain. 


\section{Descriptive Evidence}

Table 2 shows the change in log real monthly labour earnings over a 10 -year period by the type of overtime compensation for overtime hours worked in the relevant period. ${ }^{\text {Gorkers }}$ with no overtime at all experience a median real earnings growth of roughly $7 \%$, while the $25^{\text {th }}$ percentile of their real earnings growth distribution is negative ( -7 log points) and their $75^{\text {th }}$ percentile is $17 \log$ points. If we calculate the 10 -year growth in real labour earnings for workers with either paid overtime or no overtime at all, we find that their median labour earnings growth is about $10 \%$ and the $25^{\text {th }}$ and $75^{\text {th }}$ percentile are $5 \%$ and $22 \%$, respectively. If we calculate the median growth in earnings for workers with "working time accounts" at least in one year and any combination of paid overtime and no overtime work in the remaining years, median growth in real earnings is remarkably higher at $14 \%$ for these group of workers as is the $25^{\text {th }}$ - and $75^{\text {th }}$ percentile of their earnings growth distribution. If we additionally allow for unpaid overtime in at least one year and any combination of other forms of overtime compensation or no overtime at all in the remaining years, we do find the highest median growth in real labour earnings for this group of workers (25 log points) as well as the highest $25^{\text {th }}\left(11 \log\right.$ points) and $75^{\text {th }}$ percentiles (48 $\log$ points). Hence, a naive comparison of groups of workers with different overtime incidence and different overtime compensation patterns shows varying patterns of wage growth over a 10-year period and in particular finds that the group of workers with at least some incidence of unpaid overtime over the 10-year period experiences the highest median wage growth.

\section{Econometric Analysis}

\section{Estimation Strategy}

Our wage measure is the real monthly labour earnings including possible paid overtime earnings as well as the monthly share of performance-related pay received in the relevant

\footnotetext{
5 See Table A1 in the Appendix for descriptive statistics of all variables for our subsample.
} 
year. In our empirical work we use the following framework similar to the one suggested by Hunt (1999) and apply it to the problem at hand. The straight-time hourly wage of a worker i in year $\mathrm{t}$ is modeled as

$$
\ln \left(w_{i t}^{h}\right)=\theta_{1}\left(\frac{\sum_{t=1}^{s_{i}} \text { otup }_{i t}}{\sum_{t=1}^{s_{i}} I_{i t}}\right)+\theta_{2}\left(\frac{\sum_{t=1}^{s_{i}} \text { otwacc }_{i t}}{\sum_{t=1}^{s_{i}} I_{i t}}\right)+X_{i t} \beta+\gamma_{i} t+\alpha_{i}+\varepsilon_{i t}
$$

where $w_{i t}^{h}$ is the straight-time hourly wage, otup $_{i t}$ is the average weekly amount of unpaid overtime, measured by the difference of average actual hours worked including any overtime and bargained weekly standard hours $h_{s}$ and combined with the information on the type of overtime compensation, otwacc $_{i t}$ is the average weekly amount of overtime compensated with extra days off later on,$I_{i t}$ is an indicator variable with $I_{i t}=1$ if a valid observation is available, $X_{i t}$ is a vector of additional characteristics, $\gamma_{i} t$ is an individual-specific time trend in labour earnings, which allows for heterogeneous individual growth rates, $\alpha_{i}$ is an individual fixed effect and $\varepsilon_{i t}$ is an error term.

The monthly wage $w_{i t}^{m}$ is defined as

$$
w_{i t}^{m}=w_{i t}^{h}\left(4.33 * h_{s}+(1+p) * O T_{M}^{P}\right)
$$

where $\mathrm{p}$ is the overtime premium and $O T_{M}^{P}\left(0.5 * O T_{M}^{P}\right)$ is the amount of overtime hours worked in the month where monthly labour earnings including any overtime is collected if their overtime is usually paid (partly paid/partly compensated with extra time off).

Combining (1) and (2), the log of the monthly labour earnings can be expressed as

\footnotetext{
6 If the respondent answers that overtime work is usually partly paid, partly compensated with extra days off later on, we use half of the average amount of overtime worked.

7 The approximation $\log (1+\mathrm{x}) \approx \mathrm{x}$ is applied in step 3 .
} 
(3)

$$
\begin{aligned}
& \ln \left(w_{i t}^{m}\right)=\theta_{1}\left(\frac{\sum_{t=1}^{s_{i}} \text { otup }_{i t}}{\sum_{t=1}^{s_{i}} I_{i t}}\right)+\theta_{2}\left(\frac{\sum_{t=1}^{s_{i}} \text { otwacc }_{i t}}{\sum_{t=1}^{s_{i}} I_{i t}}\right)+X_{i t} \beta+\gamma_{i} t+\alpha_{i}+\varepsilon_{i t}+\ln \left[4.33 h_{s}+(1+p) O T_{M}^{P}\right] \\
& =\theta_{1}\left(\frac{\sum_{t=1}^{s_{i}} \text { otup }_{i t}}{\sum_{t=1}^{s_{i}} I_{i t}}\right)+\theta_{2}\left(\frac{\sum_{t=1}^{s_{i}} \text { otwacc }_{i t}}{\sum_{t=1}^{s_{i}} I_{i t}}\right)+X_{i t} \beta+\gamma_{i} t+\alpha_{i}+\varepsilon_{i t}+\ln (4.33)+\ln \left(h_{s}\right)+\ln \left(1+\frac{(1+p) O T_{M}^{P}}{4.33 h_{s}}\right) \\
& \approx \theta_{1}\left(\frac{\sum_{t=1}^{s_{i}} \text { otup }_{i t}}{\sum_{t=1}^{s_{i}} I_{i t}}\right)+\theta_{2}\left(\frac{\sum_{t=1}^{s_{i}} \text { otwacc }_{i t}}{\sum_{t=1}^{s_{i}} I_{i t}}\right)+X_{i t} \beta+\ln (4.33)+\ln \left(h_{s}\right)+\frac{(1+p) O T_{M}^{P}}{4.33 h_{s}}+\gamma_{i} t+\alpha_{i}+\varepsilon_{i t}
\end{aligned}
$$

The parameters of primary interest are $\theta_{1}$ and $\theta_{2}$. They pick up the correlation with $\ln \left(w_{i z}^{m}\right)$ of the cumulative average amount of unpaid overtime per week, and the cumulative average amount of overtime worked per week within a working time account scheme for the period $\mathrm{t}=1$ to $\mathrm{t}=\mathrm{z}$, respectively. They are therefore indicators for cumulative effects of unpaid overtime (working time accounts). The reason for explicitly modelling the cumulative effect of working time accounts is twofold: First, these accounts sometimes are not balanced within the bargained period and are thus essentially "converted" to unpaid overtime. Second, we do observe an increase in long-term working time accounts, where workers accumulate overtime deposits over very long periods and we want to pick up the earnings effects of this persistent overtime effort over a longer time period.

We estimate two versions of equation (3). The first one employs the restriction $\gamma_{i}=0$ and thus amounts to estimating a standard fixed-effects model. The second version allows for fixed effects as well as an individual specific time trend in monthly real labour earnings. This specification picks up unobserved individual characteristics that influence not only the wage level, but that also have an impact on the individual specific rate of earnings growth. Note furthermore, that due to the fact that we analyse a sample of firm stayers the general 
specification also wipes out firm specific fixed effects and implicitly controls for a firm specific real earnings trend. The estimated parameter for $\ln \left(h_{s}\right)$ is restricted to 1 , but we do not impose a restriction on $(1+p)$ since overtime premiums might vary across workers and imposing the average German overtime premium of $p=0.25$ slightly influences our estimates of $\theta_{1}$ and $\theta_{2}$. We estimate both versions separately for male and female workers. Standard errors are robust to heteroscedasticity in the standard fixed effects estimation. The full model is estimated by first differencing equation (3), wiping out $\alpha_{i}$, and then applying a Within estimator to the resulting equation in order to sweep out $\gamma_{i}$. Standard errors in this case are adjusted for heteroscedasticity and serial correlation along the lines suggested by Arellano (1987)

To sketch long-term effects of overtime work that is not directly remunerated we use the full unbalanced set of observations of workers in our subsample with at least an observed 10-year growth in labour earnings. Longitudinal attrition factors, calculated from the staying probabilities supplied with the survey, are used in all estimations in order to take into account panel attrition. The X vector includes bargained weekly standard hours $h_{s}$ and a variable for the number of within firm job changes. A full set of time dummies is also included in all specifications.

In our basic specification (equation 3) the parameter for the effect of the cumulative average amount of unpaid overtime per week $\left(\theta_{1}\right)$ does not interplay with observed tenure in the "starting year" for each worker in our data. However, one might think that the timing of investment into unpaid overtime is important, i.e. conditional on person/firm fixed effects as well as person/firm specific time trends it still matters whether a worker in his first or in his

\footnotetext{
8 See also Greene (2000) for a discussion of this procedure, which is a combination of the White and the Newey-West estimator.

9 See Wooldridge (2002, pp. 577) for a detailed discussion.
} 
tenth year with the firm works unpaid overtime over a certain period. To control for this interplay, we estimate a modified version of equation (3) for our male subsample, where we allow for interactions of quartiles of observed tenure at the beginning of each employment spell with the firm and the subsequent cumulative average amount of unpaid overtime per week.

\section{Results}

Table 3 displays the results of our estimation exercise. Column 1 and 2 show the results for male and female workers employing the restriction $\gamma_{i}=0$, i.e., using a standard fixed effects model. The estimated parameters for the cumulative average effect of unpaid overtime are in both cases significantly positive and the effect for females is slightly highet 10 than the one for males. Hence, we do find long-term effects of unpaid overtime: A persistent increase in average unpaid overtime work of one hour per week goes along with an increase in hourly real labour earnings of $2 \log$ points for male workers and 3 log points for female workers. Note that this result holds while controlling for the number of internal job changes in previous years. On average one internal job change is associated with an increase in hourly real earnings of $8 \log$ points.

The estimated parameter for the cumulative average effect of overtime worked which is compensated by extra days off later on is significantly positive for male workers and significantly higher $\left(\chi^{2}(1)=8.2\right)$ than the corresponding one for unpaid overtime worked. Working overtime persistently within a working time account scheme is therefore also correlated with long-term earnings for men in the restricted specification. This is consistent with at least two explanations: (1) As mentioned above deposits in working time accounts are often "converted" to unpaid overtime after the phasing out of the balancing period. Under this

\footnotetext{
${ }^{10}$ The difference in the estimated coefficients between male and female workers with respect to unpaid overtime is not significantly different from zero in a pooled model with interaction terms for gender and overtime work.

${ }^{11}$ If we allow for interactions of our cumulative average overtime variables and the variable "number of job changes" the regressions yield significantly positive coefficients for these interaction terms.
} 
assumption the estimated parameters for both types of overtime work should be similar. (2) Workers with remarkable amounts of worked overtime within a working time accounts scheme might have unobserved characteristics that also have an impact on their individual earnings growth, e.g., high ability workers are the first to be chosen by employers to work overtime compensated by extra days off later on when cyclical fluctuations of product demand require additional labour input. We do not pick up such effects by a standard fixed effects approach.

For females we also do observe a significantly positive parameter of overtime worked within a working time account scheme which is similar to the one for unpaid overtime $\frac{12}{12}$. As opposed to male workers however, we cannot reject the null hypothesis that the estimated coefficients for the two types of cumulative average overtime are identical for female workers $\left(\chi^{2}(1)=1.3\right)$.

Our estimates for the effect of straight-time working hours are significantly negative for male and female workers and confirm earlier results for the time period 1984 to 1994 provided by Hunt (1999): a one-hour reduction in standard working hours is associated with a rise in hourly labour earnings of roughly $2 \%$.

It is possible that workers with high unobserved abilities not only have a higher earnings level but also have higher labour earnings growth due to, for example, employer learning about workers abilities. As outlined above, this might bias our estimates. To check for potential bias from unobserved heterogeneity related to individual wage growth, we estimate equation (3) without imposing the restriction $\gamma_{i}=0$. Column 3 and 4 reveal the results of this exercise.

With respect to male workers, the estimated coefficient for the cumulative average amount of unpaid overtime is significantly positive and identical to the one in the restricted specification. Hence, we do find again significant long-term labour earnings effects associated with unpaid

\footnotetext{
${ }^{12}$ Note however, that we do find significant gender differences in estimated coefficients in a pooled model with interactions of gender and overtime work with respect to working time accounts
} 
overtime. The estimated coefficients for the cumulative average effect of overtime work compensated by extra days off later on is only weakly significantly positive $(\alpha=0.1)$. Hence, controlling for heterogeneous individual earnings growth rates absorbs the former correlation between cumulative average overtime worked with extra days off later on and real labour earnings for male workers. This is for example consistent with high ability workers primarily chosen by employers when overtime work is required, as mentioned above.

Considering the cumulative effects of not straightly paid overtime for female workers, we find that neither of the estimated parameters are significantly different from zero. Hence, controlling for heterogeneous individual earnings growth rates picks up the former correlation between both types of overtime work and real labour earnings for females. Therefore, we do find significant long-term earnings differentials between male and female workers with respect to unpaid overtime. Our results fit for example into the "sticky floor" model of pay and promotion suggested by Booth et al. (2002), which is consistent with their empirical evidence for Great Britain based on the BHPS. They argue that women are just as likely as men to be promoted and therefore receive an initial wage increase on promotion. However, due to either worse market alternatives or to less positive firm responses to outside offers for women, women receive lower wage gains consequent upon promotion. In view of our estimates for West Germany this might imply that higher ability women experience higher individual earnings growth, but that controlling for individual earnings trends due to unobserved heterogeneity we do not find additional returns to investments into unpaid overtime for them in the longer run.

The estimated coefficients of straight-time hours are robust against the change in the empirical specification for male and female workers. Note, that taking into account heterogeneous individual earnings growth rates leads to insignificant parameter estimates for within firm mobility. 
So far, our empirical specification does not allow for interactions of tenure at the beginning of each individual employment spell and subsequent cumulative unpaid overtime. However, one might think that the timing of investment into unpaid overtime might be important. Therefore, we estimate a modified version of equation (3) for our male subsample including four interactions of quartile dummies for tenure in the "starting year" 13 and our measure of the cumulative average amount of unpaid overtime per week instead of the main effect $\theta_{1}$. Column 5 of Table 3 displays the results for the random growth specification. The estimated parameters for the interaction of subsequent cumulative average effect of unpaid overtime and quartiles of tenure in the first year of the observed spell are significantly positive for all quartiles but the $25^{\text {th }}$ percentile and the significant coefficients are similar in size to the overall estimate of $\theta_{1}$. Hence, for all male workers except for the group with tenure in the "starting year" less than 4.5 years we do observe a significant effect of the cumulative average amount of unpaid overtime on hourly labour earnings.

In order to illustrate the magnitude of the cumulative average effect of unpaid overtime on earnings found in our data, we conduct a simple and rough calculation. We compute the mean of the real monthly labour earnings for male workers with no incidence of unpaid overtime for each year from 1990 to 1999. We then assume that a worker with this average labour earnings persistently increases the amount of weekly unpaid overtime by 5 hours (minimum average number of unpaid overtime hours in that period, Table 2), ceteris paribus. The cumulative increase in real labor earnings over the 10 year period sums up to a total of $€ 32211$.

\section{Checks of robustness}

Our results rely on a subsample of firm stayers with an observed (unbalanced) 10-year period of earnings growth. To check the robustness of our analysis, we rerun our regressions (random growth model) for subsamples of firm stayers with at least 3-year, 5-year and 7-year

\footnotetext{
${ }^{13}$ The values for tenure in the "starting year" are $\mathrm{q}(.25)=4.5$ years, $\mathrm{q}(.50)=10$ years and $\mathrm{q}(.75)=16$ years.
} 
periods of earnings growth. Additionally, we introduce a simple test for sample selection bias in these regression exercises. Following Wooldridge (2002, pp. 581) we add two binary sample selection indicators to our set of regressors, i.e. we compute lead dummies that indicate whether a worker moves to a new employer within the next two years and therefore drops out of our sample or not. Since sample selection in a fixed effects framework is only relevant if selection is correlated with the idosyncratic errors, the estimated parameters for the lead variables (drop out in $\mathrm{t}+1$ or $\mathrm{t}+2$ ) should not be significant in $\mathrm{t}$ under the null hypothesis. The first 3 columns in Table 4 display our results. First of all, we do not discover any support for the hypothesis that our sample selection criteria influence the estimated parameters of interest, since none of the estimated parameters for the leads of the selection indicator is significantly different from zero. Considering the estimated $\widehat{\theta}_{1}$ 's for male workers, we find that the estimated parameters for the cumulative average amount of unpaid overtime are robust against changes in the selection criteria. This is also true with respect to the size of the estimated parameters for the cumulative average effect of overtime work compensated by extra days off later. However, we do observe slight changes in the significance level $(\alpha=5 \%$ versus $\alpha=10 \%$ ) in this case. Considering the results for female workers, we do not find any significant changes for the cumulative average effect of overtime work compensated by extra days off later. This is also true for size of the estimated parameters for the cumulative average effect of unpaid overtime. However the significance level slightly varies: For the 3-year time span the results are insignificant as for the 10-year time span while we do find a significant impact of cumulative average unpaid overtime for the other two time periods $(\alpha=5 \%)$.

One might argue that education matters within our context and that our empirical specification with fixed individual effects and an individual specific time trend in labour earnings does not

\footnotetext{
14 Technically, for our subsample of firm stayers with at least an observed 3-year period of earnings growth this implies that someone with observations for the years 1988 to 1996 who moves to a new employer in 1995 is in our sample with all observations from 1988 to 1994 and lead2=1 for 1993 and 1994 and lead1=1 for 1994 .
} 
take this into account in an appropriate way. Therefore, we allow for an interaction of tenure and education (measured by dummies for apprenticeship and university degree) in our standard fixed effects approach (specification 1) and estimate the model using first differences to eliminate the fixed effects. ${ }^{15}$ The results (column 4 ) are in line with those of our prefered specification (specification 2). With respect to male workers we find again a significant effect of the cumulative average amount of unpaid overtime, which is only slightly lower $\left(\widehat{\theta}_{1}=\right.$ 0.01). However, for female workers we do not find a significant correlation between unpaid overtime and labour earnings.

To check for observed individual earnings dynamics instead of allowing for an individual earnings trend, we estimate a dynamic version of equation (3) by means of including a lagged dependent variable and applying the restriction $\gamma_{i}=0$. We apply the (biased) Within estimator to both subsamples. ${ }^{16}$ With respect to male workers, the estimated parameter for the cumulative average amount of unpaid overtime is significant and identical to the one presented in Table 3. The estimated parameter for the cumulative average effect of overtime work compensated by extra days off later on is also significant and only slightly lower $\left(\widehat{\theta_{2}}=\right.$ 0.01). Considering the estimates for our subsample of female workers the estimated parameters for both cumulative overtime variables do not change at all. The estimated parameter for the lagged dependent variable is significant in both cases with a size of 0.3 .

\section{Conclusions}

This study finds remarkable long-term real labour earnings effects associated with unpaid overtime for male firm stayers in West Germany: A persistent increase in average unpaid

\footnotetext{
15 We also estimate the random growth model for the education group "apprenticeship" for males. The results remain constant.

${ }^{16}$ We also employed the GMM-estimator suggested by Arellano and Bond. However, it turned out that the estimated parameters for the lagged dependent variable are very small (less than 0.1 ) for our sample of male workers and sometimes even negative for female workers.
} 
overtime work of one hour per week goes along with an increase in hourly real labour earnings of 2 percent, ceteris paribus. Hence, we provide supportive evidence for the hypothesis that the notion of unpaid overtime might be misleading - at least in the long run. Rather, we might think of unpaid overtime as a current investment of workers which leads on average to notable returns on investment later on.

Moreover, taking into account that unobserved individual characteristics influence not only the level of real labour earnings but also individual real labour earnings growth, we find some evidence that the significantly positive long-term real labour earnings effect of unpaid overtime for female workers disappears. This might point to the fact that high ability (and high effort) women receive higher earnings growth, but firms do respond differently to additional effort in terms of unpaid overtime for women and men owing to discrimination. 


\section{References}

Arellano, M. (1987), Computing robust standard errors for within-groups estimators, Oxford Bulletin of Economics and Statistics, Vol. 49, 431-434.

Bauer, T.K. and K. F. Zimmermann (1999), Overtime work and overtime compensation in Germany, , Vol. 46, Scottish Journal of Political Economy, 419-436.

Bell, D.N.F. and R. A. Hart (1999), Unpaid work, Economica, , Vol. 66, 271-290.

Bell, D.N.F., R. A. Hart, O. Hübler and W. Schwerdt (2000), Paid and unpaid overtime working in Germany and the UK, IZA DP 133, Bonn.

Bell, L.A. and R.B. Freeman (2001), The incentive to work hard: explaining hours worked differences in the US and Germany, Labour Economics, Vol. 8, 181-202.

Booth, A.L. and M. Francesconi (2000), Job mobility in 1990s Britain: does gender matter?, Research in Labour Economics, Vol. 19, 173-189.

Booth, A.L., M. Francesconi and J. Frank (2002), A sticky wage model of promotion, pay and gender, European Economic Review (forthcoming).

Francesconi, Marco (2001), Determinants and consequences of promotions in Britain, Oxford Bulletin of Economics and Statistics, Vol. 63, 279-310.

Greene, W. (2000), Econometric Analysis, London.

Hunt, J. (1999), Has work-sharing worked in Germany?, The Quarterly Journal of Economics, Vol. 114, 117-148.

Kalwij, A.S. and M. Gregory (2002), Times they are a changing? The use of paid overtime in the British labour market, DP Oxford.

Pannenberg, M. (2002), Weiterbildungsinvestitionen und Überstundenaktivität. Eine vergleichende Studie für Westdeutschland und Großbritannien, in: Backes-Gellner, U., C. Schmidtke (Eds.): Bildungssystem und betriebliche Beschäftigungsstrategien in internationaler Perspektive, Schriften des Vereins für Sozialpolitik, 37-58.

Pannenberg, M. and G.G. Wagner (2001), Overtime Work, Overtime Compensation and the Distribution of Economic Well-Being. Evidence for West Germany and Great Britain, IZA DP 318, Bonn.

SOEP Group (2001), The German Socio-Economic Panel after more than 15 years Overview, Vierteljahrshefte zur Wirtschaftsforschung, Vol. 70, 7-14. (pdf-file at http://www.diw.de/english/publikationen).

Trejo, Stephen J. (1991), The effects of overtime pay regulation on worker compensation, American Economic Review, Vol. 81, 719-740.

Wagner, G., R. Burkhauser and F. Behringer (1993), The English language public use file of the German Socio-Economic Panel, The Journal of Human Resources, Vol. 28, 429-433.

Wooldridge, J.M. (2002), Econometric Analysis of Cross Section and Panel Data, Cambridge. 
Table 1: Compensation of Overtime Work

\begin{tabular}{|c|c|c|c|c|c|c|c|c|c|c|c|c|}
\hline Year & 1988 & 1989 & 1990 & 1991 & 1992 & 1993 & 1994 & 1995 & 1996 & 1997 & 1998 & 1999 \\
\hline \multicolumn{13}{|l|}{ Share of overtime compensation (in \%) } \\
\hline - paid overtime & 41.4 & 42.5 & 42.3 & 42.4 & 40.4 & 37.8 & 32.7 & 34.0 & 29.3 & 22.1 & 21.3 & 17.1 \\
\hline - extra days off later on & 18.7 & 19.9 & 19.4 & 22.1 & 21.1 & 21.5 & 23.8 & 24.3 & 29.1 & 30.8 & 35.9 & 39.7 \\
\hline - partly paid, partly extra days off later on & 16.5 & 15.1 & 17.6 & 17.3 & 21.5 & 19.6 & 22.1 & 22.2 & 19.9 & 25.1 & 23.7 & 25.3 \\
\hline - unpaid overtime & 23.4 & 22.5 & 20.7 & 18.2 & 16.9 & 21.1 & 21.3 & 19.4 & 21.7 & 22.7 & 19.9 & 17.9 \\
\hline \multicolumn{13}{|l|}{ Number of overtime hours (per week;ot=1) } \\
\hline - paid overtime & 4.6 & 5.0 & 4.8 & 4.8 & 4.6 & 4.8 & 4.1 & 5.1 & 5.0 & 4.6 & 5.2 & 5.9 \\
\hline - extra days off later on & 3.2 & 3.3 & 2.9 & 3.2 & 3.2 & 3.3 & 3.7 & 3.6 & 3.4 & 3.6 & 3.4 & 3.9 \\
\hline - partly paid, partly extra days off later on & 4.7 & 4.8 & 4.3 & 4.6 & 4.7 & 4.5 & 4.5 & 5.0 & 4.2 & 5.1 & 5.1 & 4.9 \\
\hline - unpaid overtime & 6.0 & 5.8 & 5.0 & 6.1 & 5.7 & 5.8 & 5.2 & 5.0 & 5.7 & 5.7 & 6.6 & 6.3 \\
\hline
\end{tabular}

Source: GSOEP, sample of firm stayers; sample weights are used.

Table 2: 10-year Growth in Real Monthly Labour Earnings

- changes in log monthly earnings -

\begin{tabular}{lccc}
\hline Type of compensation of overtime work & Median & $25^{\text {th }}$-percentile & $75^{\text {th }}$-percentile \\
\hline - no overtime at all & 0.07 & -0.07 & 0.17 \\
- only paid overtime in at least 1 year & 0.10 & -0.05 & 0.22 \\
- working time accounts in at least 1 year & 0.14 & 0.04 & 0.29 \\
- unpaid overtime in at least 1 year & 0.25 & 0.11 & 0.48 \\
\hline
\end{tabular}

Source: GSOEP, sample of firm stayers; sample weights are used. 
Table 3: Overtime Work and Real Labour Earnings

\begin{tabular}{|c|c|c|c|c|c|c|}
\hline & \multicolumn{2}{|c|}{$\begin{array}{l}\text { Specification } 1 \\
\text { (equation } 3 \text { ) }\end{array}$} & \multicolumn{2}{|c|}{$\begin{array}{l}\text { Specification } 2 \\
\text { (equation } 3 \text { ) }\end{array}$} & \multirow{2}{*}{\multicolumn{2}{|c|}{$\begin{array}{c}\text { Interaction with tenure at } \\
\text { start of firm specific spell } \\
\text { - Specification 2- } \\
\text { male }\end{array}$}} \\
\hline & male & female & male & female & & \\
\hline $\begin{array}{l}\text { cumulative average amount } \\
\text { of unpaid overtime }\left(\widehat{\theta}_{1}\right)\end{array}$ & $\begin{array}{l}0.02 \\
{[0.004]}\end{array}$ & $\begin{array}{l}0.03 \\
{[0.011]}\end{array}$ & $\begin{array}{l}0.02 \\
{[0.006]}\end{array}$ & $\begin{array}{l}0.03 \\
{[0.024]}\end{array}$ & $\widehat{\theta_{1}^{q_{25}}}$ & $\begin{array}{l}0.00 \\
{[0.010]}\end{array}$ \\
\hline $\begin{array}{l}\text { cumulative average amount } \\
\text { of overtime with extra days } \\
\text { off later on }\left(\widehat{\theta_{2}}\right)\end{array}$ & $\begin{array}{l}0.04 \\
{[0.004]}\end{array}$ & $\begin{array}{l}0.02 \\
{[0.007]}\end{array}$ & $\begin{array}{l}0.01 \\
{[0.005]}\end{array}$ & $\begin{array}{l}0.01 \\
{[0.009]}\end{array}$ & $\widehat{\theta_{2}^{9.50}}$ & $\begin{array}{l}0.02 \\
{[0.009]}\end{array}$ \\
\hline current paid overtime & $\begin{array}{l}0.61 \\
{[0.046]}\end{array}$ & $\begin{array}{l}0.70 \\
{[0.121]}\end{array}$ & $\begin{array}{l}0.48 \\
{[0.059]}\end{array}$ & $\begin{array}{l}0.48 \\
{[0.116]}\end{array}$ & $\widehat{\theta_{3}^{q^{7.5}}}$ & $\begin{array}{l}0.02 \\
{[0.008]}\end{array}$ \\
\hline standard hours $h_{s}$ & $\begin{array}{l}-0.02 \\
{[0.002]}\end{array}$ & $\begin{array}{l}-0.02 \\
{[0.003]}\end{array}$ & $\begin{array}{l}-0.03 \\
{[0.002]}\end{array}$ & $\begin{array}{l}-0.02 \\
{[0.003]}\end{array}$ & $\widehat{\theta_{4}^{>q_{75}}}$ & $\begin{array}{l}0.03 \\
{[0.014]}\end{array}$ \\
\hline $\begin{array}{l}\text { within firm mobility } \\
\text { (number of job changes) }\end{array}$ & $\begin{array}{l}0.08 \\
{[0.012]}\end{array}$ & $\begin{array}{l}0.05 \\
{[0.020]}\end{array}$ & $\begin{array}{l}-0.01 \\
{[0.020]}\end{array}$ & $\begin{array}{l}0.01 \\
{[0.026]}\end{array}$ & -- & -- \\
\hline $\begin{array}{l}\text { Wald_X (d.f.) } \\
\text { Number of Observations } \\
\text { Number of Individuals }\end{array}$ & $\begin{array}{c}1815.8(16) \\
5813 \\
558 \\
\end{array}$ & $\begin{array}{c}450.6(16) \\
1617 \\
158 \\
\end{array}$ & $\begin{array}{c}353.6(15) \\
4798 \\
549\end{array}$ & $\begin{array}{c}114.8(15) \\
1336 \\
155\end{array}$ & & $\begin{array}{c}396.0(18) \\
4798 \\
549 \\
\end{array}$ \\
\hline
\end{tabular}

Source: GSOEP, sample of firm stayers; longitudinal attrition factors are used.

Panel data models based on equation (3) of main text with parameter restriction $\delta=1$ for $\ln \left(\mathrm{h}_{\mathrm{s}}\right)$.

Specification (1): Imposing $\gamma_{i}=0$. Specification (2): no restriction on $\gamma_{i}$.

$\widehat{\theta_{k}^{q_{*}}}$ : parameter for $\left(\sum^{s}\right.$ otup $\left._{i t} / \sum^{s} I_{i t}\right) * \mathrm{q}_{* * \text { th }}$ with $\mathrm{q}_{* * \text { th }}=1$ for $*$ th quartile of tenure in "starting year" $($ values: $5,10,16)$

Full sets of time dummies are included.

Robust standard errors in parentheses.

Wald_X: Wald - Test with $\mathrm{H}_{0}$ : no joint significance of all unrestricted regressors. 
Table 4: Checks of Robustness

\begin{tabular}{|c|c|c|c|c|c|c|c|c|}
\hline & \multicolumn{2}{|c|}{ 3-year-window } & \multicolumn{2}{|c|}{ 5-year-window } & \multicolumn{2}{|c|}{ 7-year-window } & \multicolumn{2}{|c|}{$\begin{array}{c}\text { interaction with } \\
\text { education }\end{array}$} \\
\hline & male & female & male & female & male & female & male & female \\
\hline cumulative average amount & 0.01 & 0.01 & 0.01 & 0.02 & 0.01 & 0.03 & 0.02 & 0.03 \\
\hline of unpaid overtime $\left(\widehat{\theta}_{1}\right)$ & {$[0.004]$} & {$[0.008]$} & {$[0.004]$} & {$[0.009]$} & {$[0.005]$} & {$[0.014]$} & {$[0.006]$} & [0.024] \\
\hline cumulative average amount & 0.01 & 0.003 & 0.01 & 0.005 & 0.01 & 0.01 & 0.01 & 0.01 \\
\hline $\begin{array}{l}\text { of overtime with extra days } \\
\text { off later on }\left(\widehat{\theta_{2}}\right)\end{array}$ & {$[0.004]$} & {$[0.006]$} & [0.004] & {$[0.006]$} & {$[0.005]$} & {$[0.01]$} & {$[0.005]$} & [0.009] \\
\hline selection indicator & -0.03 & -0.03 & -0.03 & -0.06 & -0.03 & -0.06 & -- & -- \\
\hline$\widehat{S_{i, t+1}}$ & {$[0.02]$} & {$[0.028]$} & {$[0.023]$} & {$[0.04]$} & {$[0.02]$} & {$[0.05]$} & & \\
\hline selection indicator & -0.001 & -0.009 & 0.005 & 0.001 & 0.006 & 0.02 & -- & -- \\
\hline$\widehat{S_{i, t+2}}$ & {$[0.02]$} & {$[0.02]$} & {$[0.07]$} & {$[0.025]$} & {$[0.02]$} & {$[0.02]$} & & \\
\hline Wald_X (d.f.) & $\begin{array}{c}1802.0 \\
(17)\end{array}$ & $\begin{array}{c}265.7 \\
(17)\end{array}$ & $\begin{array}{c}1438.7 \\
(17)\end{array}$ & $\begin{array}{c}204.5 \\
(17)\end{array}$ & $\begin{array}{c}947.4 \\
(17)\end{array}$ & $\begin{array}{c}156.8 \\
(17)\end{array}$ & $\begin{array}{c}1462.3 \\
(17)\end{array}$ & $\begin{array}{c}142.3 \\
(17)\end{array}$ \\
\hline Number of Observations & 11642 & 4035 & 10044 & 3256 & 8050 & 2434 & 4798 & 1336 \\
\hline Number of Individuals & 1967 & 745 & 1482 & 512 & 1053 & 330 & 549 & 155 \\
\hline
\end{tabular}

Source: GSOEP, samples of firm stayers; longitudinal attrition factors are used.

Column 1-6: Panel data models based on equation (3) of main text with parameter restriction $\delta=1$ for $\ln \left(h_{\mathrm{s}}\right)$.

Column 7-8: First Difference estimator of equation (3) with $\gamma_{\mathrm{i}}=0$. and $\delta=1$ for $\ln \left(\mathrm{h}_{\mathrm{s}}\right)$

Full sets of time dummies are included.

Robust standard errors in parentheses.

Wald_X: Wald - Test with $\mathrm{H}_{0}$ : no joint significance of all unrestricted regressors. 


\section{Appendix:}

Table A1: Summary Statistics

\begin{tabular}{|c|c|c|}
\hline Variable & Mean & Standard Deviation \\
\hline Male & 0.78 & -- \\
\hline Log of monthly real labour earnings & 8.46 & 0.35 \\
\hline $\begin{array}{l}\text { Cumulative average amount of } \\
\text { unpaid overtime (per week) }\end{array}$ & 0.36 & 1.53 \\
\hline $\begin{array}{l}\text { Cumulative average amount of } \\
\text { overtime with extra days off later on } \\
\text { (per week) }\end{array}$ & 0.64 & 1.31 \\
\hline$O T_{M}^{P}$ & 0.03 & 0.07 \\
\hline \multicolumn{3}{|l|}{$4.33 h_{s}$} \\
\hline Bargained weekly standard hours & 38.13 & 1.81 \\
\hline $\begin{array}{l}\text { Within firm mobility (number of job } \\
\text { changes) }\end{array}$ & 0.13 & 0.41 \\
\hline Number of Observations & 7430 & \\
\hline
\end{tabular}

Source: GSOEP, sample of firm stayers. 


\section{IZA Discussion Papers}

No. Author(s)

597

598

599

600

601

602

603

604

605

606

607

608

609
M. Gerfin

M. Lechner

H. Steiger

S. M. Fuess, Jr. M. Millea

D. Del Boca

A. Lusardi

H. N. Mocan

B. Scafidi

E. Tekin

J. S. Lauerová

K. Terrell

Š. Jurajda

K. Terrell

L. Locher

T. Andrén

B. Gustafsson

S. P. Jenkins

C. Schluter

C. Grund

Y. Zenou

G. Saint-Paul

G. Saint-Paul

A. Heitmueller

G. Saint-Paul

J. J. Dolado

M. Jansen

J. F. Jimeno

P. Kuhn

M. Skuterud

M. Pannenberg
Title

Area

Date

Disentangling Pay and Productivity in a

5

$10 / 02$

Corporatist Economy: The Case of Germany

Credit Market Constraints and Labor Market

2

$10 / 02$

Decisions

Catholic Schools and Bad Behavior

5

$10 / 02$

Explaining Gender Differences in Unemployment

4 with Micro Data on Flows in Post-Communist Economies

What Drives the Speed of Job Reallocation

5

during Episodes of Massive Adjustment?

Migration in the Soviet Successor States

2

$10 / 02$

Income Effects from Labor Market Training

Programs in Sweden During the 80's and 90's

2

The Effect of Family Income during Childhood on 5

Later-Life Attainment: Evidence from Germany

The Wage Policy of Firms - Comparative

5

$10 / 02$

Evidence for the U.S. and Germany from

Personnel Data

Does Subsidised Temporary Employment Get

3 the Unemployed Back to Work? An Econometric Analysis of Two Different Schemes

How Do Firms Redline Workers?

5

$10 / 02$

Economic Aspects of Human Cloning and

3

$10 / 02$

Reprogenetics

Cognitive Ability and Paternalism

3

$10 / 02$

Unemployment Benefits, Risk Aversion, and

4

$10 / 02$

Migration Incentives

Some Thoughts on Macroeconomic Fluctuations and the Timing of Labor Market Reform

A Matching Model of Crowding-Out and On-the-

2 Job Search (with an Application to Spain)

Internet Job Search and Unemployment 